- Short communication

\title{
RADIOACTIVITY LEVELS IN WATER-HYACINTH SAMPLES OF MAJOR WATER-BODIES IN THE DISTRICT OF JESSORE, BANGLADESH
}

\author{
K.A. KABIR, S.M.A. ISLAM ${ }^{*}$ AND M.M. RAHMAN ${ }^{1}$ \\ Department of Physics, Jahangirnagar University, Savar, Dhaka, Bangladesh
}

\begin{abstract}
Natural and fallout radioactivity concentrations in the water-hyacinth samples collected from 22 major water-bodies of the district of Jessore, Bangladesh, were measured with a low level gamma ray spectrometry system consisting of a high resolution HPGe coaxial detector. Energy and efficiency calibration of the detector have been done with the standard sources supplied by the International Atomic Energy Agency (IAEA).
\end{abstract}

Key words: Baor, Natural lake, Radioactivity, Water-hyacinth

Although water hyacinth (Eichhornia crassipes) is considered in many countries as a weed and is responsible for many problems, many individuals, groups and institutions have been able to turn the problem around and find useful applications for the plant. The plant itself has a fibrous tissue and a high energy and protein content, and can be used for a variety of useful applications. Such as, production of paper, fibre board, yarn and rope, charcoal briquetting, fish feed, fertilizers, biogas etc. In this way water hyacinth goes further close to human being and if it contains radionuclides, it contributes to the dose received by humans not only through external exposure but also through internal exposure due to their ingestion and inhalation. Sources of radioactivity in the aquatic environment include naturally occurring radionuclides, fallout from the atmospheric, runoff from watersheds that have received atmospheric deposition, and radioactive effluents from medical, industrial, and nuclear facilities released either accidentally or routinely. Depending upon the element and the chemical form, radionuclides may accumulate in bottom sediment or remain in the water column in the dissolved state. From either location, they can subsequently accumulate in aquatic plant and be transferred through the aquatic food chain or through its various products as mentioned earlier. Contamination of the environment by radionuclides inevitably results in an increase in the radiation exposure of natural populations of organisms that occupy the contaminated area. Many studies have shown that water hyacinth can be used to accumulate high concentrations of organic as well as inorganic pollutants (Colleen et al. 1999, Rice 1965, Shawky et al. 2005 and Upadhyay et al. 2007). In this study, baors were chosen because of its great importance based on the different uses and its surroundings, namely recreation, tourism, fisheries, agricultural and industrial water source, etc. In the

\footnotetext{
* Corresponding author: <azharphyd@yahoo.com>.

${ }^{1}$ Health Physics Division, Atomic Energy Center, Post Box No. 164, Dhaka, Bangladesh.
} 
present study the natural radioactivity in water hyacinth collected from the above mentioned natural lakes was determined from their ${ }^{226} \mathrm{Ra},{ }^{232} \mathrm{Th}$ and ${ }^{40} \mathrm{~K}$ activity concentrations. Attempts were also made to measure long-lived artificial radionuclides, particularly the $662 \mathrm{KeV}$ peak due to ${ }^{137} \mathrm{Cs}$ in those samples. Since there is no previous information on radioactivity level in water hyacinth due to these radionuclides in the district of Jessore, the present study would serve as base-line data for water-hyacinth in particular and for aquatic plants in general.

Sample collection and preparation were performed following the method recommended by the IAEA. Instrumental set-up and energy and efficiency calibration of the HPGe detecting system were also accomplished according to the recommendation of the IAEA.

Table 1 presents the calculated radioactivity concentration of radionuclides for 22 water hyacinth samples collected from different areas of the district of Jessore.

Table 1. Activity concentrations of radionuclides in water-hyacinth samples (Bq/kg) across the district of Jessore.

\begin{tabular}{lccccc}
\hline \multirow{2}{*}{ Location } & \multirow{2}{*}{ Sl. No. } & \multicolumn{4}{c}{ Activity Concentration( Bq/kg } \\
\cline { 3 - 6 } & & ${ }^{226} \mathrm{Ra}$ & ${ }^{232} \mathrm{Th}$ & ${ }^{40} \mathrm{~K}$ & ${ }^{137} \mathrm{Cs}$ \\
\hline Chaugachha & 1 & $22.98 \pm 2.73$ & $40.25 \pm 9.31$ & $800.38 \pm 86.25$ & - \\
Thana & 2 & $25.33 \pm 24.22$ & $37.54 \pm 8.01$ & $654.42 \pm 87.38$ & - \\
& 3 & $9.01 \pm 1.08$ & $31.65 \pm 8.29$ & $715.61 \pm 79.65$ & - \\
Jessore Sadar & 4 & $16.55 \pm 1.43$ & $20.89 \pm 1.23$ & $319.29 \pm 72.59$ & - \\
Thana & 5 & $20.15 \pm 1.89$ & $56.23 \pm 2.42$ & $1176.20 \pm 106.59$ & - \\
& 6 & $44.29 \pm 2.51$ & $29.36 \pm 1.57$ & $1227.08 \pm 88.74$ & - \\
Bagherpara & 7 & $27.24 \pm 1.94$ & $36.27 \pm 8.17$ & $786.73 \pm 85.30$ & - \\
Thana & 8 & $35.20 \pm 2.46$ & $50.99 \pm 2.27$ & $1003.46 \pm 102.11$ & - \\
& 9 & $45.99 \pm 2.25$ & $35.66 \pm 6.63$ & $1100.49 \pm 70.60$ & - \\
Sharsha & 10 & $34.83 \pm 2.54$ & $30.73 \pm 1.84$ & $909.30 \pm 113.91$ & - \\
Thana & 11 & $24.11 \pm 1.78$ & $31.43 \pm 7.74$ & $677.68 \pm 80.92$ & - \\
& 12 & $26.95 \pm 14.26$ & $59.10 \pm 10.47$ & $598.80 \pm 91.46$ & - \\
Jhikargachha & 13 & $44.39 \pm 2.92$ & $21.51 \pm 1.56$ & $1079.73 \pm 114.52$ & - \\
Thana & 14 & $23.31 \pm 1.62$ & $25.22 \pm 6.60$ & $473.27 \pm 68.38$ & - \\
& 15 & $21.88 \pm 1.79$ & $42.53 \pm 9.52$ & $648.36 \pm 88.55$ & - \\
Abhainagar & 16 & $35.77 \pm 2.56$ & $31.34 \pm 1.84$ & $455.78 \pm 107.60$ & - \\
Thana & 17 & $20.27 \pm 2.63$ & $21.10 \pm 1.32$ & $671.44 \pm 83.82$ & - \\
& 18 & $32.28 \pm 2.02$ & $25.73 \pm 6.84$ & $683.39 \pm 74.90$ & - \\
Manirampur & 19 & $29.43 \pm 2.53$ & $24.10 \pm 1.30$ & $462.38 \pm 69.57$ & - \\
Thana & 20 & $30.26 \pm 2.11$ & $35.89 \pm 10.37$ & $949.37 \pm 88.70$ & - \\
& 21 & $26.15 \pm 1.73$ & $22.94 \pm 6.18$ & $383.61 \pm 65.30$ & - \\
Keshabpur & 22 & $96.77 \pm 4.30$ & $53.86 \pm 2.46$ & $976.71 \pm 117.40$ & - \\
Thana & & $31.51 \pm 17.22$ & $34.74 \pm 11.63$ & $761.52 \pm 262.54$ & - \\
Average \pm SD & & & & & \\
& & & & &
\end{tabular}

In the present study the activity concentration of ${ }^{226} \mathrm{Ra}$ was found to range from 9.01 \pm 1.08 to $96.77 \pm 4.30 \mathrm{~Bq} / \mathrm{kg}$ with mean value of $31.51 \pm 17.22 \mathrm{~Bq} / \mathrm{kg}$. The activity concentration of ${ }^{232} \mathrm{Th}$ was found to range from $20.89 \pm 1.23$ to $59.10 \pm 10.47 \mathrm{~Bq} / \mathrm{kg}$ with mean value of $34.74 \pm 11.63 \mathrm{~Bq} / \mathrm{kg}$ and that of ${ }^{40} \mathrm{~K}$ from $319.29 \pm 72.59$ to $1227.08 \pm$ 88.74 Bq/kg the mean value being $761.52 \pm 262.54 \mathrm{~Bq} / \mathrm{kg}$. The errors quoted represent 
the counting error for individual measurements and standard deviation for means. The maximum and minimum values are given. Table 1 shows that in water-hyacinth, the activity concentration of thorium is higher than radium, which is evident from the fact that thorium is 1.5 times higher than uranium in earth's crust (Aswathanarayana 1985). So the present results in this regard are in line with expectation. It is also observed that the measured activity concentration of ${ }^{40} \mathrm{~K}$ exceeds markedly the values of both radium and thorium. Present results show that in all the water-hyacinth samples ${ }^{40} \mathrm{~K}$ represents more than $80 \%$ of the natural radioactivity. Potassium is a universal constituent of the earth's crust and it is the most abundant radioactive element under consideration (Lambrechts et al. 1987). Moreover, the excessive use of the potassium containing fertilizers in the area adjacent to the sampling sites may contribute to the availability of ${ }^{40} \mathrm{~K}$ to be uptaken by water-hyacinth. Water-hyacinth is an aquatic plant which can live and reproduce floating freely on the surface of fresh waters and/or can be anchored in mud. So it uptakes radionuclides from both water and sediment. On the other hand, biological systems regulate tissue concentrations of potassium to a constant level under ambient conditions (Dougherty 1989). So, the relatively higher and nearly uniform values of ${ }^{40} \mathrm{~K}$ activity in water-hyacinth samples is not unusual and has been observed in other biological systems in other studies in other part of Bangladesh and the world.

No detectable activity of ${ }^{137} \mathrm{Cs}$ was observed in the water-hyacinth samples under study. This is simply because this region used to be free of nuclear activities with no history of nuclear test. This region is also very much far from sites of previous nuclear accidents such as Chernobyl and Hiroshima. It implies, therefore, that there can have no radioactivity due to fallout in water-hyacinth in the area of the district of Jessore.

\section{REFERENCES}

Aswathanarayana U. 1985. Principles of Nuclear Geology, (Ozonian Press Pvt Ltd, New Delhi), 85-87.

Colleen Kelley, Randall E. Mielke, Darryl Dimaquibo, Abigale J. Curtis, and Jane G. Dewitt. 1999. Adsorption of Eu(III) onto Roots of Water-hyacinth, Environ. Sci. Technol. 33(9), 1439-1443.

Dougherty G. 1989. Environmental Radioactivity Levels in Marine Species from Malaysia and Fiji, Health Physics. 57(1), 187-190.

Lambrechts A. and L. Foulquier. 1987. Radioecology of the Rhone Basin: Data on the Fish of the Rhone (1974-1984). J. Environ. Radioactivity 5(2), 205-221.

Rice, T. R. 1965. The role of plants and animals in cycling of radionuclides in the marine environment. Health Physics 11, 953-964.

Shawky, S., M. A. Geleel and A. Aly, 2005. Sorption of Uranium by Non-Living Water Hyacinth Roots, Journal of Radioanalytical and Nuclear Chemistry 265(1), 81-84,

Upadhyay, Alka R. and B. D. Tripathi. 2007. Principle and Process of Biofiltration of Cd, Cr, Co, $\mathrm{Ni} \& \mathrm{~Pb}$ from Tropical Opencast Coalmine Effluent. Water, Air, \& Soil Pollution (Springer), 180(1-4), 213-223. 